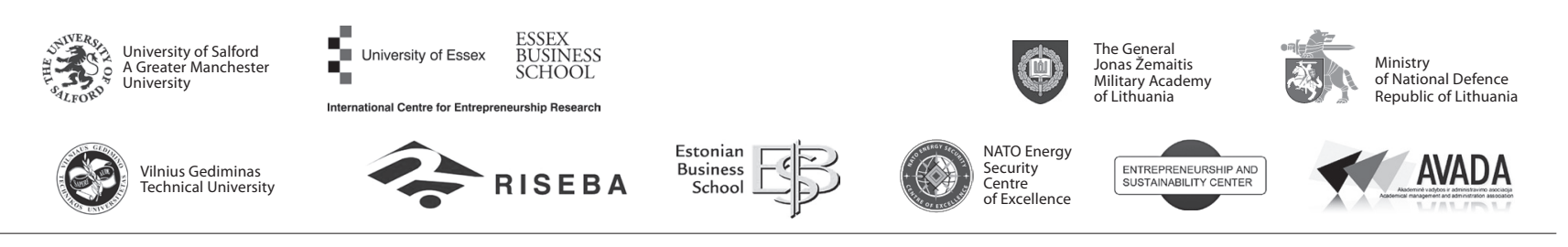

\author{
JOURNAL OF SECURITY AND SUSTAINABILITY ISSUES \\ ISSN 2029-7017 print/ISSN 2029-7025 online \\ 2017 March Volume 6 Number 3 \\ http://dx.doi.org/10.9770/jssi.2017.6.3(1)
}

\title{
SECURE DEVELOPMENT OF COUNTRY AND COMPETITIVENESS ISSUES: CASE OF GERMANY'S ENERGY SECURITY
}

\author{
Yuriy Bilan', Wadim Strielkowski², Rolf Karbach³, Grzegorz Mentel ${ }^{4}$ \\ ${ }^{1}$ Research Associate, Centre of Applied Economic Research, Faculty of Management and Economics, \\ Tomas Bata University in Zlin, 5139 Mostni Str., Zlin, 760 01, Czech Republic \\ ${ }^{2}$ University of Cambridge, 13 Trumpington street, CB2 1AG, Cambridge United Kingdom \\ ${ }^{3}$ Department of Management and Human Resource Development, Faculty of Social and economic relations, \\ University of Alexander Dubcek in Trencin, Študentská 1638/3, 91150 Trenčín, Slovakia \\ ${ }^{4}$ Rzeszów University of Technology, Faculty of Management, al. Powstańców Warszawy 12 35-959 Rzeszów, Poland

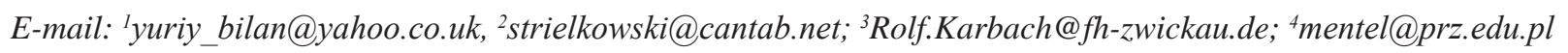

Received 20 September 2016; accepted 20 December 2016

\begin{abstract}
Security and competitiveness are two very important aspects of the economic and political development of every country. In the 21 st century, one of the key drivers of most economies in countries throughout the world is energy. Different countries adopt different measures so as to ensure their security and competitiveness through the effective energy policies that make traditional and renewable resources adequately available hence eliminating the possibilities of shortages. Our paper takes up the case study of Germany as one of the wealthiest and most developed economies in the European Union which also occupies the first positions in the charts of energy uptake and consumption. German policy-makers realize its vulnerability when it comes to energy security and attempt to diversify its energy competitiveness using the renewable sources of energy (for instance via the adoption of the Erneuerbare-Energien-Gesetz or the "Renewable Energy Act" (EEG)). We analyze the issues of energy security and competitiveness of a country using an example of Germany. Moreover, we describe what challenges the renewable energy sources (RES) might bring into the conventional game and how this might influence the competitiveness and security.
\end{abstract}

Keywords: energy, sustainable development, renewable energy sources, security, competitiveness, Germany, European Union

Reference to this paper should be made as follows: Bilan, Y.; Strielkowski, W.; Karbach, R.; Mentel, G 2017. Secure development of country and competitiveness issues: case of Germany's energy security, Journal of Security and Sustainability Issues 6(3): 329-342. http://dx.doi.org/10.9770/jssi.2017.6.3(1)

\section{Introduction}

In the 21 st century, one of the key drivers of most economies in countries throughout the world is energy. As such different countries have adopted different measures so as to ensure their security and competitiveness through the effective energy policies that make traditional and renewable resources adequately available hence eliminating the possibilities of shortages.

A common platitude in the contemporary world is the essence of security, and the vital role it plays in the economic development of any nation. In the absence of security, development is unlikely to occur. The reverse is also true. Conversely, a society with no access to their country`s resources is at a risk of facing many problems. This paper has an aim of establishing the factors surrounding the secure development of a country. Currently the issue of energy security has become a matter of concern for a country that is focusing on secure develop- 
ment (Balitskiy et al., 2016). Energy security mainly focuses on the efforts to provide affordable and reliable sources of fuels, both for generation of electricity and transport (Asif and Muneer, 2007). It can also refer to the uninterrupted available of energy sources (Ferreira et al., 2013). This form of security can be divided into two. The first part, long-term energy sources focuses on investments to supply energy which are in line with economic development of a nation and also adhere to environmental needs (Stern, 2014; Štreimikienè and Kasperowicz, 2016). The second part which is the short term energy mainly deals with the abrupt changes that affect the energy system and its capacity to react on time (Koohi-Kamali et al., 2013).

Majority of the developing nations globally are highly reliant on external energy sources. Their main focus is on ensuring a secure source of obtaining such energy from a diversified network in order to avoid shortage. The risk of deficiency is likely to stall development. Meeting the basic household requirements is a major focus point for most economies (Correlje and Van der Linde, 2006). These issues are also on the table in the European Union (EU). For quite some time now, the EU has been seeking variable solutions for securing the stable and steady sources of energy (gas, coal, or other, perhaps, renewable and viable sources of energy) for its Member States thus ending the situation in which it has to face insecurity and uncertainty associated with the necessity to buy energy elsewhere or to import it from other non-EU countries at a high price (and at even higher costs of political bargaining). For this reason, the EU promotes the decisive steps for action and offers an opportunity for its Member States to seek external sources of energy whenever they are unable to afford those that are available (O'Keeffe et al., 2016). On the other hand, they act as price determiners owing to the fact that they can control the energy being offered to members. This enables them to have a bargaining power, which is very important in avoiding overexploitation of consumers by the producers. Thus, finding how to increase a country's competitiveness through its energy independency can be a solution for securing the development of many countries, not just the EU Member States.

Energy security and competitiveness constitute the key basis for any country's steady and peaceful development and growth. In this paper, we show how independence from the foreign sources of energy might foster the development of a country's economy and lead it towards the stable path. This paper is organized as follows: Section 2 describes the energy security and competitiveness issues in the EU. We analyze the recent development and provide examples of how energy security goes hand in hand with the climate protection policies of the EU. Section 3 briefly discusses the issue of renewable energy sources (RES) in the context of energy security and competitiveness. Section 4 analyzes the case study of Germany, as a country with rapid economic growth, high energy consumption, and even higher energy dependency. Section 5 discusses the use of renewables as a possible substitute to the solid fuels and traditional energy sources using the recent example from Germany. Finally, section 6 provides conclusions and policy implications.

\section{Energy security and competitiveness in the EU}

The European Union is known to import more than $50 \%$ of the energy consumed by member countries (Timmer et al., 2013). Crude oil forms a significant portion of this import. The total energy imported can go to as high as a $€ 1$ billion in a single day (Chalvatzis and Hooper, 2009). Countries are also known to rely entirely on one source of energy and thus any shortage may impact greatly on their development. This vulnerability is also likely to spike prices in some instances. Some strategies have, however, been released by the European Union to secure developing member states. This move is projected to impact positive changes in the utilization of energy sources. The measures are as narrated below in greater detail. First of all, the short term incentives include: completely halting gas imports from Russia, and disrupting the gas imports from Russia via Ukraine (Richter and Holz, 2015) These measures are meant to prepare the EU in the event that a shortage occurs. It was discovered that countries in the Eastern part would be adversely affected (Chalvatzis and Hooper, 2009). On the other hand, the fact that all countries were required to be in liaison would guarantee consumers diversified supply in case a shortage occurred (Maltby, 2013). Such preparedness has proved to be essential in ensuring that the developing economies are not derailed. There are also a number of long-term incentives in line with European Union`s program. These focus majorly on five major areas. The first part is on increasing the efficiency of energy in order to be in line with the required 2030 environmental requirements (Le Coq and Paltseva, 2009; 
Strielkowski 2016; Simelyte et al.; 2016; Barberis et al., 2017). The chief priority here is to focus on the buildings. Efficient energy sources are to be used in order to reduce on energy costs incurred in this sector (Aghaei et al., 2013; Traversari et al.; 2017; Crosbie et al. 2017; Passerini et al., 2017).

It also enables requires that the consumers lower their consumption of energy (Le Coq and Paltseva, 2009; Marques and Almeida, 2013; Tvaronavičiené 2016; Rezk et al. 2016; García-Fuentes et al. 2017; Perfido et al. 2017; Oates et al. 2017; Daher et al. 2017; Lynch et al. 2017). Increase in production of energy sources among members is another crucial measure. Countries have been known to produce sustainable fossil fuels and safe nuclear components which are later used to produce energy (Dincer and Ancar, 2015). In the same way the developing nations can equally negotiate with their suppliers for fairer prices.

A completion in the internal market is another major step which the EU was intent on introducing. This missing links would in essence be able to cater for the many disruptions being experienced. In addition, sources of energy would be redirected to countries that were in dire need. Member countries were also required to inform the EU in advance regarding their plans to outsource from outside the confines of the organization `s jurisdiction. This would ensure that the EU is able to create a security plan. In a similar manner, consolidation and protection of critical infrastructure by monitoring and coordinating with existing storage amenities both regionally and internationally (Menegaki, 2011). This would enable the EU to assess risk and also generate a reverse system of flows.

Security of energy which is supplied to developing countries bonded with the European Union by various trade and association agreements is based on the fact the market is an exemplification of a politically charged economy (Scarlat et al., 2015). Conversely, the empires revolve around a world that is divided into political and economic sectors. This involves a situation where countries compete for available resources and only those that are sufficiently well endowed manage to win this war. The developing nations thus remain unsecured. The EU has a strategy that involves diversification of financial integration (Gârleanu et al., 2015). As such, the policies on energy will become an integral part of the external trade conducted by the organization in relation to security.

Energy is a social amenity which is here to stay. Its inevitability springs directly from the fact that it is a basic necessity for human survival. This indicates the reason why developing nations are entirely reliant on energy as a key constituent of their growth (Kasperowicz, 2014). The continued use of fossil fuels is likely to create a shortage leading to the depletion of reserves in the near future (Abas et al., 2015). Global warming and other significant issues have also hiked prices of fuel making it impossible for some nations to afford (Menegaki, 2011). The solution to these growing energy demands has turned out to be the adoption of sustainable renewable energy sources. The sources are available in abundance and are highly inexhaustible. Further still, they do not pose a threat to the environment. The EU is encouraging its members to start adopting these sources of energy since they will come in handy in case the existing fossil fuels become unavailable (Vasseur and Kemp, 2015; Urbaniec, 2015). This will move to secure the development of any country.

It is impossible to separate development and security. Both are core aspects that are essential for any nation. A country can have the potential to accomplish many things but as long as there is insecurity, it remains to be a futile dream. This is one of the reasons why many nations have set aside a lot of resources meant to secure their wellbeing (Umbach, 2010). Insecurity may come in many forms and it does not necessarily have to be inflicted by causing bodily harm. Its impact may be felt owing to the deprivation of key essential needs of any developing country. It is the duty of the already developed economies to encourage those that are in their early stages of growth, by providing them with the necessary tools (Bruton et al., 2015). The fact that the world population is likely to grow tremendously within the next two decades is a matter of major concern. If small nations will not have developed by then. Their citizens will be grappling for survival. This will in turn affect the entire world. Thus the need to secure the development of these countries. 


\section{Renewable energy sources in the context of energy security}

Renewable energy appears to be one of the cheapest and affordable ways how the secure the way to go in order to secure development of a country in terms of its dependence on external energy sources. Such energy is bound to reduce the cost of living and also decrease the expenditure on some of the essential needs such as electricity (Umbach, 2010). A nation that depends on itself has higher chances of developing without having to over depend on an already developed economy. Additionally, this renewable energy is likely to strike a balance between energy from other harmful sources, such as that polluting the environment and one that is environmentally friendly (Martínez and Piña, 2016). The government also has a major role to play in assisting local producers of renewable energy sources. Its aid may be in form of subsidies such as in India where solar energy was greatly transformed by the government initiative (Jaeger and Michaelowa, 2015). On the other hand, provision of low interest loans to the producers is another major step towards enabling them to create a better life for the rest of the citizens.

Additionally, the government is in a position to collect more revenue and spend less on exporting energy products (Alley, 2016). This will ensure that the additional revenue is channeled towards developmental agendas. Affordability is a major concern for most households in any developing economy (Chong et al., 2015). A significant portion of their income, usually about $20 \%$ or more is spent on energy (Gillingham et al., 2016). This means that a rise in the price of energy is likely to adversely affect them. Subsidies would therefore be effective in this scenario, to provide cleaner energy and to better their way of life. This is gradually going to increase the household income level and concurrently reduce the poverty margin.

Energy security in many of the households can be attained through the introduction of biomass and other substitute sources of energy (Chalvatzis and Hooper, 2009). This source of energy is clean and readily available. All that the citizens need is government aid to assist them produce the energy at their homes (Sovacool and Dworkin, 2015). The pollution in most households is greatly reduced by this source of energy. This nonetheless, ensures forest conservations, owing to the fact that people will not have to depend entirely on wood and charcoal (Bele et al., 2015). On a global scale, the move is likely to impact on the climate, and gradually reduce global warming.

Recently, a report by the World Bank indicated that air pollution is one of the major causes of deaths in the contemporary world (Asif and Muneer, 2007). The impact that renewable energy would have is therefore very great. Respiratory illnesses will reduce tremendously, and resources will therefore be channeled to deal with more alarming issues, this having being solved. One of the most efficient government interventions, is Thailand's ENCON fund (Chalvatzis \& Hooper, 2009). This fund comprises of duty imposed on the petroleum products coming into the currently (Al-Salem, 2015). The fund is used to provide loans at low interest rates to the private investors. This in turn enables the latter to focus on producing renewable energy products.

There is a comparative advantage in being a Member State of the European Union. EU Members are able to receive commodities at affordable prices (Puffer et al., 2016). The countries affiliated to the organizations can also get short term and long term loans to assist in their developments (Moss et al., 2015). Stipends provided by members are used to create a pool of resources for them to tap into in case of a crisis. Such would occur for instance where there is a deprivation of energy by the producers. The union is also persistent in negotiating with the energy providers on behalf of its members, making it easier for them to access energy at affordable prices (Khalfallah, 2015). An addition to that would be the fact that having the necessary resources, the developed nations are in a position to offer education on energy to underdeveloped countries. The diagram below indicates some of the essential constitutions of energy security.

Energy is bound to remain a major issue in the future. How well the issue on energy security is handled will be the main determinant of development in most countries. The above examples point towards a future of prospective prosperity so long as the developmental agendas are put ahead of everything. Time has come to shift to more efficient and affordable energy sources. The impact is that it will benefit the entire world. It will also be 
in line with environmental objectives pertaining to climate change. The government and non-governmental authorities therefore have a major task in ensuring that their countries remain secure. Depletion of energy sources is not supposed to sound a warning alarm on them; rather, they should be ready to cope with any eventuality. There is therefore no doubt that energy security is core in determining the development of any nation.

\section{Energy security and competitiveness: German experience}

Federal Republic of Germany (or simply Germany), a founding member of the European Union (EU) is a case which clearly demonstrates that there are advantages that any country accrues from being an EU member and its largest economy. German economy consumes a lot of energy and there is a dire need to place the issue energy security among the first priorities. The most common sources of energy used in Germany include fossil fuels, nuclear power, biomass, the wind, hydro and solar (Carrasco et al., 2006). Germany is a major importer of energy in the EU, and as such, it faces stiff competition from other nations in the EU and also from other countries outside the EU. Of late, the country is putting in policies to regulate the use of nuclear power and thus becoming a major importer.

One of the richest and most developed economies in the EU, Germany is also ranked $1^{\text {st }}$ in Europe and $6^{\text {th }}$ in the world by its energy uptake and consumption. The most common sources of energy used in Germany include fossil fuels, nuclear power, biomass, the wind, hydro and solar, although around 30 percent of Germany's electrical power is also acquired from renewable storage. Furthermore, in some pick primes wind and solar provided close to $80 \%$ off peak charge at specific moments of the day on specific days. Germany intends a $35 \%$ average share by the year 2020. Chart 1 that follows demonstrates the energy balance in Germany in 1990-2014. There is a clear shift from the solid fuels, petroleum products and gases to renewable energy sources (RES).

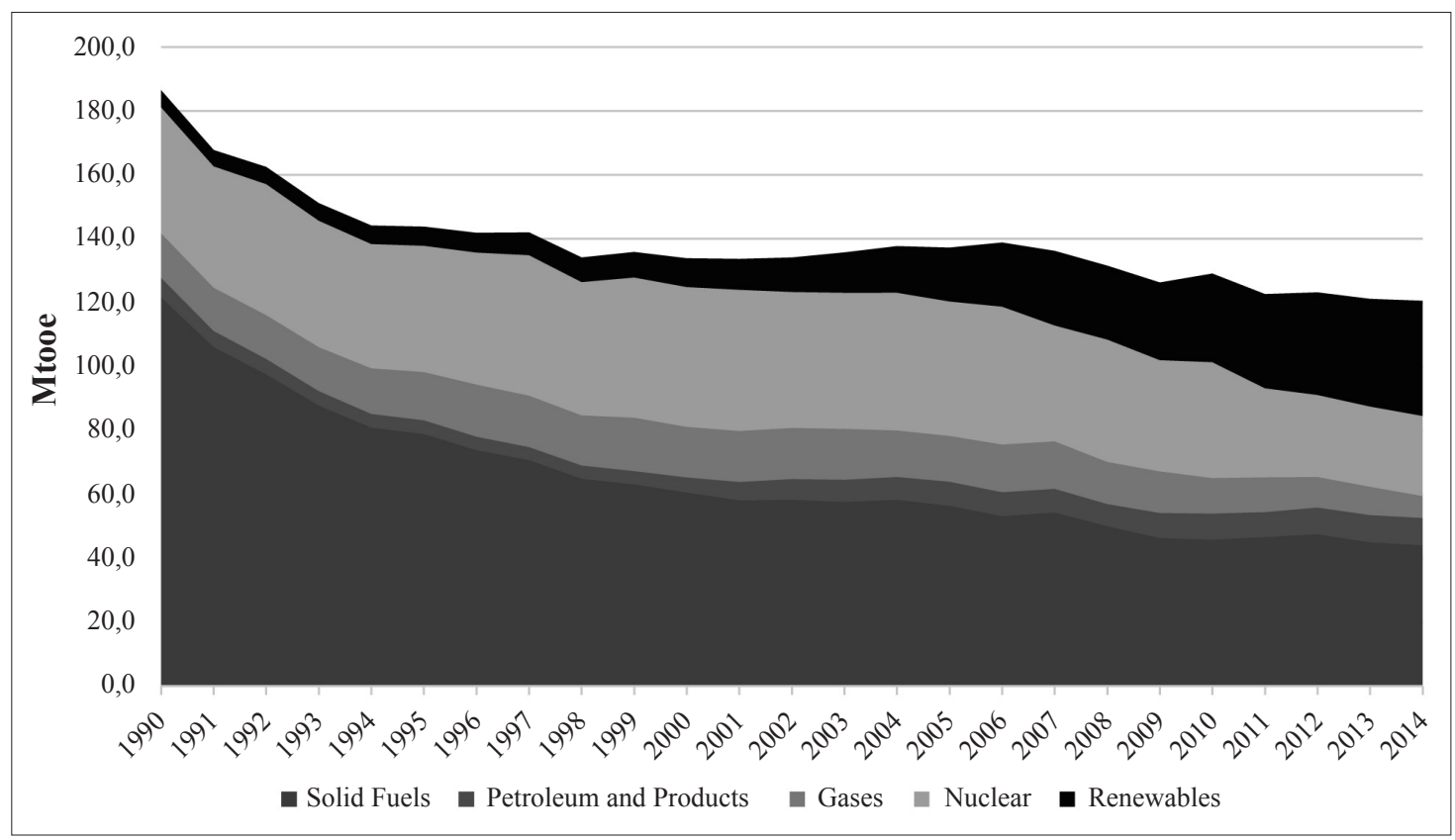

Chart 1. Energy balance in Germany (1990-2014)

Source: European Commission (2016)

The German experience with Erneuerbare-Energien-Gesetz (Renewable Energy Act or EEG) shows that if the total subsidy cost of electric energy is retrieved through per unit charges, then clearly recovering subsidies through metered consumption results in shift of subsidies towards households that have not taken them up. A new tax charge on own consumption of solar of 4.4 euro cents per $\mathrm{kWh}$ ( $70 \%$ of EEG charge) was proposed for 
industrial and commercial companies in Germany to partly correct the tax arbitrage incentive (under the EEG charge), but this was later introduced at $30 \%$ of EEG and finally abolished.

Moreover, being a highly competitive economy, Germany faces many issues with its energy security (e.g. dependence on the Russian gas) and is therefore in a very volatile position that requires lots of balancing and planning. This is happening alongside with the two German major energy companies, Eon and RWE, pursuing radical restructuring as the shares of conventional coal and gas power are giving way to the renewables (mostly highly supported wind and solar energy). This shift to the renewable capacity combined with low demand and the decreasing prices of crude oil and gas, caused a collapse in the price of wholesale electricity from $€ 60$ per megawatt-hour in 2011 to about $€ 25$. Both RWE and Eon have reduced the values of their assets on their coal and gas-fired power stations. Moreover, Germany's utilities have also had to deal with the country's decision after the 2011 Fukushima disaster in Japan to abandon nuclear power.

Germany policies of energy transformation have intended to reduce to a large extent the usage of nuclear power energy as it is very hazardous to the environment (Jahn and Korolczuk, 2012). The move also intends to minimize the greenhouse effect which emits a lot of carbon into the atmosphere (Kasperowicz, 2015). As a result of this policy and the fact that Germany has a large GDP which results to the high consumption of energy, the country, therefore, is a big importer of electricity. As stated earlier, Germany faces stiff competition from other developed countries and also undeveloped countries when it comes to importing of energy as other countries still need the energy as much as Germany. Germany being in the European Union gives it advantages over other countries that are not in the union.

It is worth noting that Germany has in the recent past tried to promote the use of renewable sources of energy but it has proved to be costly because of it mainly has to rely on the natural sources of energy such as the wind and the sun (Carrascoe et al., 2006). As such, energy security policies have been put in place so as to avoid shortages because the climate plays a major role for there to be a success in the availability of energy from these renewable sources. The best and most suitable alternative that the country has taken therefore is hugely depending on the natural gas and therefore the country has no other option rather than importing. About $36 \%$ of the total gas imported by Germany comes from Russia which is not a member of the European Union. Among the countries in the European Union that Germany imports electricity from includes France.

When Germany imports energy in the form of electricity from France, a member of the European Union, it tends to have some advantages as compared to when it is importing from Russia. For instance, the European Union countries conducting business among themselves do not pay customs tax as the goods are moving from one country to the other. Other countries that are not in the union will pay the custom tax (Anderson and Reichert, 2007). It is therefore of a great advantage to Germany importing electricity from France. This is because the expenses are hugely cut, and otherwise it becomes cheaper to import gas and electricity from a country which is a member of the European Union. The European Union policies have also provided for the lowering of prices when countries in the Union are conducting their business among themselves. It, therefore, means that when Germany imports electricity from France, it will pay a lower price compared to another country which is not a member of the union that will pay a higher price.

Another advantage is that the member countries of the European Union use a common currency, the Euro. This makes doing business becomes much simpler among the member countries of the Union. As such, when Germany imports electricity from member countries of the Union such as France, it ultimately becomes less costly. This is regarding fewer protocols that are supposed to be followed compared to a country that uses other currencies (Karanfil and Li, 2015). The euro does not lose its value from one country to another unlike other countries outside the union that have different currencies that may be of less value compared to the euro and thus while importing goods and products, there is the due process of exchanging the currency, and this affects the quantity of goods imported and in this case it will affect the quantity of electricity imported which will actually be less. 
Being a member of the European Union is also an essential advantage for Germany as there are strict guidelines that outline how the countries are supposed to relate hence fostering good economic relations among the member nations. The guidelines also provide for a good understanding among the member countries in the union. This is paramount because a country may come to an agreement when it comes to the payment of the price needed when a country is importing or exporting its goods. This is very helpful for a country like Germany as it may come into an agreement with a country like France as to pay the amount in installments or at later dates depending on the agreement. There is leniency among the countries of the EU (Joumard, 2001).

This good understanding will, therefore, mean that even when Germany is facing hard economic times it can still import electricity from countries such as France that are members of the European Union depending on the terms of the agreement. This means that even if the country is not in a position to pay immediately the price of the electricity, the country can be in a suitable position to get the electricity due to the good relations between the member countries in the union. Due to the stiff competition that Germany faces today from other countries that also import electricity, it has an upper hand when it comes to the priorities of who is to be addressed first. As it is the case even in other unions throughout the world, member countries of a particular association or union first of all deal prioritize their needs before addressing the needs of other countries that are not members of that particular association. As such, when Germany approaches a country such as France and both of them are members of the European Union and another country that is not a member of the European Union also approaches France in need of importing electricity, Germany will be addressed first before the other country (Szulecki et al., 2016). This means that members of the same unions and organizations always put their interests first before the interests of other nations that are not members.

The main source of energy in Germany is the natural gas which is imported from Russia (Bilgin, 2009). Germany is the biggest importer of natural gas from Russia as it is the country with the highest population among all the countries in the continent of Europe. As it is the case, the advantages that Germany enjoys when importing from countries that are in the European Union are not there when importing from Russia as it is not a member of the European Union. As such, a custom tax must be paid. Russia does not use the euro currency but rather uses the ruble. Therefore, the due process of exchange of currency is also inevitable. All these factors put into consideration will certainly make the importing process more difficult for Germany. Also, other countries in Europe still import natural gas from Russia and thus the competition is stiff. This is because Europe's natural gas production has declined in recent years. The competition is also increased because unlike other sources of energy such as oil which can be imported or exported from continents to continents, natural gas is only limited to regions. As a result, many European nations largely depend on the natural gas from Russia (Rutland, 2008).

This stiff competition has led to Germany finding alternative measures so as to cater for the future energy supply. The country has increased energy security measures so as to avoid any cases of interruptions in future. Germany has entered into serious negotiations with Russia so as to ensure that even though there is stiff completion from other European nations for the natural gas, it is in a pole position to continue having access to the natural gas from Russia (Ríos-Mercado and Borraz-Sánchez, 2015). There are several factors that have enabled Germany to ensure that it has maintained its energy security through the continuous importation of the natural gas from Russia regardless of the stiff competition of the precious commodity from other countries. 


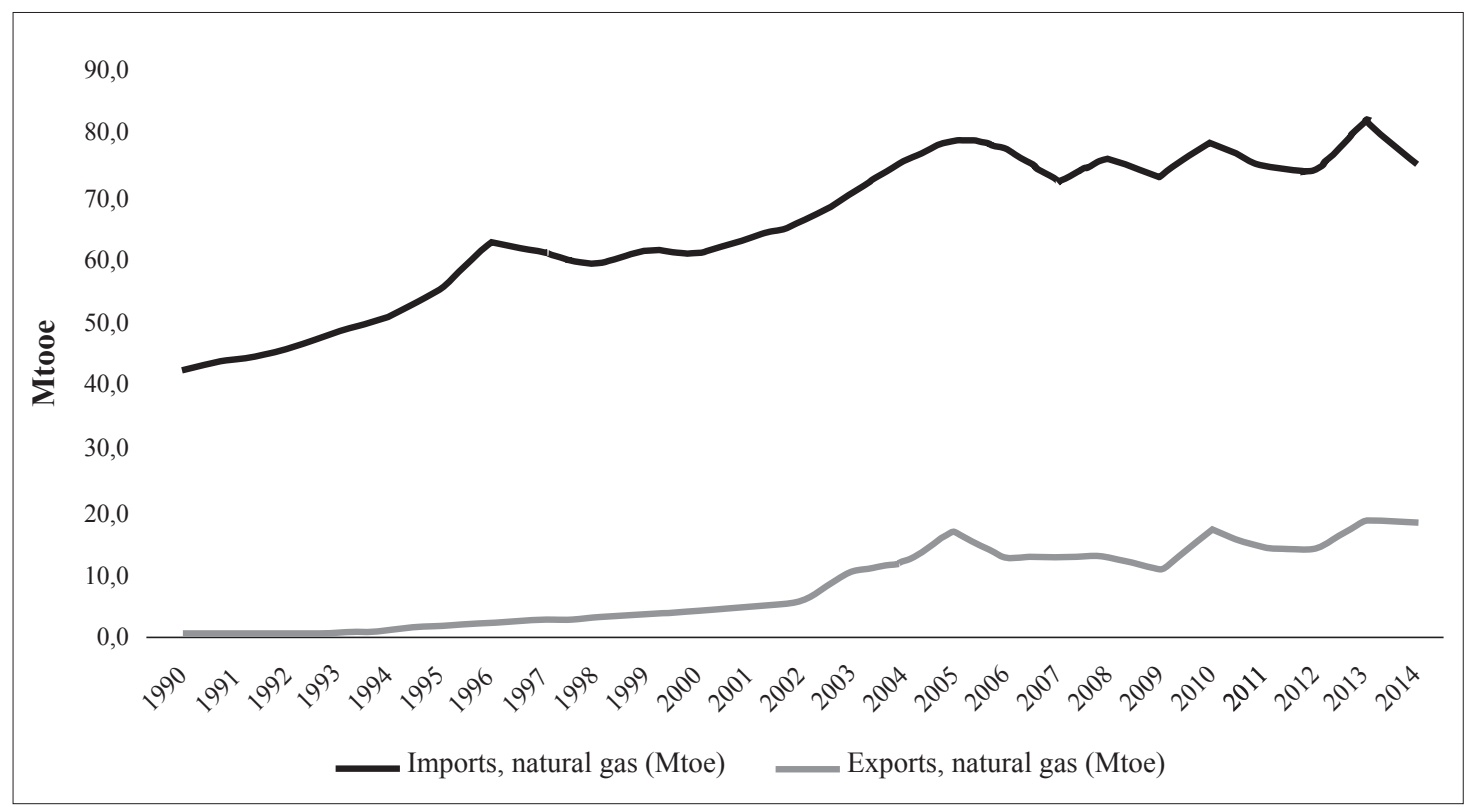

Chart 2. Import and export of natural gas in Germany (1990-2014)

Source: European Commission (2016)

Chart 2 above demonstrates the weakness of German economy when it comes to the dependency on the external sources of gas: it shows imports and exports of the natural gas over the last 15 years. From scrutinizing the information depicted on Chart 2, one can clearly see the growing pattern of consuming and importing more and more gas that the German economy is thirsty for.

On the foreign policy front, it has to be noted that Russia has long ago recognized and realized that it is a chief importer of the natural gas is Germany. Russian gas is cheap and affordable, moreover, there are existing and well-functioning pipelines that ensure its quick and smooth transfer and import.

As a result, Russia has agreed to construct a transit route for its gas. Germany has supported the idea of constructing the Nord Stream pipeline which directly connects Russia and Germany. The construction of this pipeline has very many positive effects for Germany, and it is very beneficial. First, it guarantees that Germany will continuously import the natural gas from Russia with ease. The cost will also be greatly reduced, and thus the question of energy security will be solved. Even though this is contrary to the policies undertaken by other nations such as the United States of America, in which it does not support energy security through diversification, Germany has moved on to fully support the construction. This move has also been viewed by other European nations as a rival to their pipelines and thus has not got the full support from these nations (Whist, 2007).

\section{Renewables as a substitute to traditional energy sources}

In 2011, European heads of state met so as to discuss how to complete the integration and liberalization of the internal European energy market by the year 2014. This was also a strategy of Europe's energy security policy in which the main idea was that the continent as a whole wanted to establish its fragmented energy market. The head of states agreed that it was possible to have all European member states be connected to a Europe-wide energy supply grid by the year 2015. Germany was not left behind, and it fully supported the idea. The country was represented by its leader, the Chancellor. Germany participated as it still wanted to make improvements in its energy security for the future.

The goals of the meeting as laid out were to boost energy efficiency throughout the continent of Europe. Also, it aimed at improving the coordination of how countries would continuously have access to eternal energy, and this was based on the policies that were to be revisited so as to ensure that no country is left out regarding 
acquiring energy. Market liberalization and interconnection of electric grids and pipelines was also to be put in place so as to ensure that the nations would share and have a flexible trade than it was before. The meeting also highlighted the disadvantage of many European nations relying on only one source of energy; Russia. It thus meant that in case there was a shortage of natural gas in Russia in which a majority of the countries depended on, then there would be a major crisis in the continent of Europe. If this were successful as planned in the meeting, then the problem of supply interruptions would hence be solved. From the deliberations of the meeting, all the decisions made and the agreements by the head of states have otherwise seen the process of integration and liberalization of the internal European energy market is otherwise in the process and due course, the goals of the meeting will be achieved.

As discussed, it is evident that Germany has taken great strides to improve the energy security of the nation even though there is the factor of stiff competition from other countries. Being a member of the European Union has also proved to be of great importance. However, the ways how this security can be improved are also very different and often questionable. One of the most critical aspects of that is associated with the increasing use of renewable energy sources which are treated preferentially and with a greater respect than traditional and less "green" energy sources. With regard to the above, policy-makers should be extremely careful when shifting towards the renewables due to the fact that sometimes this rapid shift might cause unintended distortions.

Several recent examples from Germany show that the challenges renewable energy sources might bring to the conventional set of play might be devastating. For instance, in June 2013 the wholesale price of electricity in Germany suddenly plunged from their positive values to the values about minus $€ 100$ per MWh. This was done in order to encourage cutbacks and protect the grid from overloading (under these circumstances, generating companies had to pay the managers of the grid to take their electricity). The plunge caused troubles with the German economy and alerted investors.

With regard to the above, the British newspaper, The Economist, described the decline of Europe's utilities from their peak in 2008, when the top 20 energy utilities were worth $€ 1$ trillion to the 2013 when their price dropped to less than half. The decline was also attributed to the widespread use of RES (The Economist, 2013). The situation reminds the case of humanitarian aid delivered in Third World countries that distorts the prices of food and ruins the traditional food producers, such as rice farmers. Too much of the renewable energy sources might mean more harm than good.

The dynamics of German electricity prices as discussed in the previous sections is shown at Chart 3 that follows. 


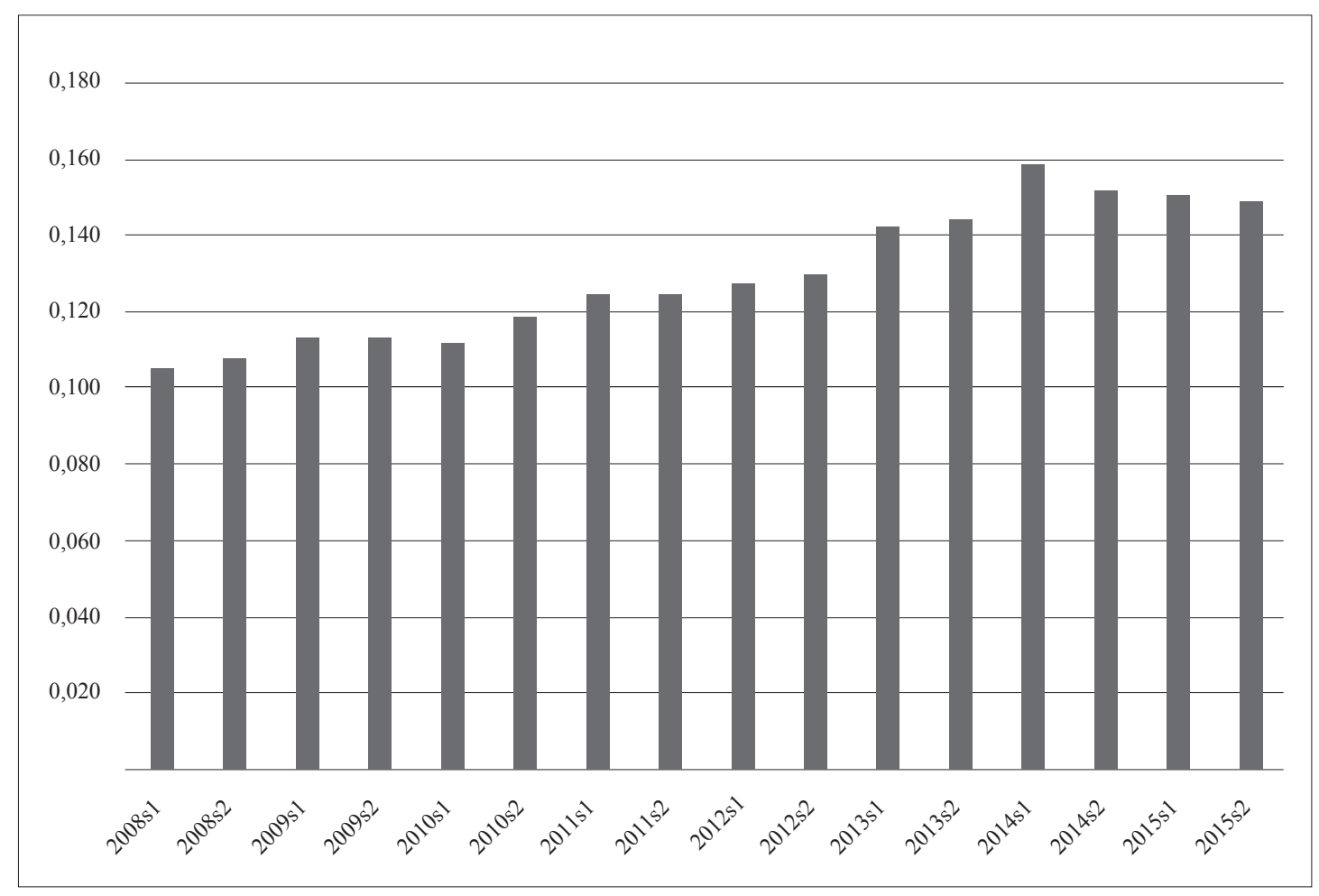

Chart 3. Electricity prices for German industrial consumers (NAT/kWh)

Source: Eurostat (2016)

From Chart 3 one can see the drop in the electricity prices in Germany. Moreover, there are more examples that involve the renewables and their devastating impact on the energy prices and energy balance. For instance, this point can be best illustrated on the example of two German major energy companies, Eon and RWE, which pursue radical restructuring as the shares of conventional coal and gas power give way to the renewables (mostly highly supported wind and solar energy).

This shift to the renewable capacity combined with low demand and the decreasing prices of crude oil and gas, caused a collapse in the price of wholesale electricity from $€ 60$ per megawatt-hour in 2011 to about $€ 25$. Both RWE and Eon have reduced the values of their assets on their coal and gas-fired power stations. Moreover, Germany's utilities have also had to deal with the country's decision after the 2011 Fukushima disaster in Japan to abandon nuclear power which caused Eon's market shares to fall 64 per cent and RWE's by three-quarters causing a record loss of $€ 7$ bn for Eon last year (Chazan, 2016). All in all, it appears that energy security and competitiveness cannot always be achieved through the massive introduction of fuel-saving and green technologies. In some cases, such measures might cause more damage to the national economy than intended and lead to the distortions and economic issues that have quite an opposite effect to those intended to secure energy independency and competitiveness.

\section{Conclusions and policy implications}

Overall, one can see that a country security and competitiveness is closely related to its dependency or independency on energy sources. Therefore, energy security and competitiveness should become a concern of any country aspiring to embark on the sustainable and steady journey towards development and growth. On the example of Germany, we demonstrated how the EU leading economy and the major energy consumer might also be vulnerable towards its suppliers of energy. The dependency of Russian gas has always been a hotlydiscussed issue in the European Union and it is unlikely it will go away any time soon. In order to achieve energy security and competitiveness, any country, including such a key player in EU and world politics, as the Federal Republic of Germany, should diversify its energy portfolio and seek for the ways how to balance it 
energy supply. These concerns often lead policy-makers and energy companies to pursuing the new research in renewable energy sources. Their popularity and their wide acceptance might offer some relief from the external energy dependency.

Neverheless, it has to be noted that renewable energy sources which are gaining wide popularity today as a solution for decarbonisation and reversing adverse consequences of climate change, do not always constitute a panacea for all economic and political diseases associated with the modern race for economic development and well-being in which so many world's developed economies have enlisted themselves. The German example presented in this paper shows that an increased focus on the renewables might distort traditional energy markets and lead to the plunge in energy and electricity prices. It is therefore recommended to consider a healthy balance of traditional and renewable energy sources, a healthy mix that is however not so easy to stir. In one way or the other, the policy-makers and stakeholders should be aware of the pitfalls lurking in the muddy waters of excessive emphasize on renewable energy. Energy security and competitiveness should be achieved through a portfolio of well-designed energy policies and strategies that should take on board the current development of world's energy prices, the state-of-the-art in the green energy research, as well as the preferences of the country's citizens who vent their political views and beliefs via the modern political system that ensures their economic well-being and security. Energy security and competitiveness is not an easy goal to achieve and it requires combined efforts of all stakeholders involved in the process. Moreover, it requires a nation-wide consensus on the visions of security and competitiveness a given economy wants to achieve.

\section{References}

Abas, N., Kalair, A., \& Khan, N. (2015). Review of fossil fuels and future energy technologies. Futures, 69, 31-49

Aghaei, J., \& Alizadeh, M. I. (2013). Demand response in smart electricity grids equipped with renewable energy sources: A review. Renewable and Sustainable Energy Reviews, 18, 64-72

Alley, I. (2016). Oil price volatility and fiscal policies in oil-exporting countries. OPEC Energy Review, 40(2), 192-211

Al-Salem, S. M. (2015). Carbon dioxide (CO 2) emission sources in Kuwait from the downstream industry: Critical analysis with a current and futuristic view. Energy, 81, 575-587

Anderson, C. J., \& Reichert, M. S. (2007). Economic benefits and support for membership in the EU: A cross-national analysis. Journal of Public Policy, 15(03), 231-249.

Asif, M., \& Muneer, T. (2007). Energy supply, its demand and security issues for developed and emerging economies. Renewable and Sustainable Energy Reviews, 11(7), 1388-1413.

Balitskiy, S., Bilan, Y., Strielkowski, W., \& Štreimikienè, D. (2016). Energy efficiency and natural gas consumption in the context of economic development in the European Union. Renewable and Sustainable Energy Reviews, 55, 156-168

Barberis, S.; Roncallo, F.; Traverso, A. (2017). Towards innovative district energy management: a case study with stochastic renewable generators, Entrepreneurship and Sustainability Issues 4(3): 294-309. http://dx.doi.org/10.9770/jesi.2017.4.3S(5)

Bele, M. Y., Sonwa, D. J., \& Tiani, A. M. (2015). Adapting the Congo Basin forests management to climate change: Linkages among biodiversity, forest loss, and human well-being. Forest Policy and Economics, 50, 1-10

Bilgin, M. (2009). Geopolitics of European natural gas demand: Supplies from Russia, Caspian and the Middle East. Energy Policy, $37(11), 4482-4492$.

Bruton, G., Khavul, S., Siegel, D., \& Wright, M. (2015). New Financial Alternatives in Seeding Entrepreneurship: Microfinance, Crowdfunding, and Peer-to-Peer Innovations. Entrepreneurship Theory and Practice, 39(1), 9-26

Carrasco, J. M., Franquelo, L. G., Bialasiewicz, J. T., Galván, E., Portillo Guisado, R. C., Prats, M. M., ...\& Moreno-Alfonso, N. (2006). Power-electronic systems for the grid integration of renewable energy sources: A survey. IEEE Transactions on industrial electronics, 53(4), 1002-1016.

Chalvatzis, K. J., \& Hooper, E. (2009). Energy security vs. climate change: theoretical framework development and experience in selected EU electricity markets. Renewable and Sustainable Energy Reviews, 13(9), 2703-2709. 
Chazan, Guy (2016). Eon and RWE pursue radical restructuring. Financial Times (18.05.2016). Available at: http://www.ft.com/cms/ s/0/316ce884-1cdc-11e6-a7bc-ee846770ec15.html

Chong, A., Karlan, D., Shapiro, J., \& Zinman, J. (2015). (Ineffective) messages to encourage recycling: evidence from a randomized evaluation in Peru. The World Bank Economic Review, 29(1), 180-206

Correlje, A., \& Van der Linde, C. (2006). Energy supply security and geopolitics: A European perspective. Energy Policy, 34 (5), $532-543$.

Crosbie, T.; Short, M.; Dawood, M.; Charlesworth, R. (2017). Demand response in blocks of buildings: opportunities and requirements, Entrepreneurship and Sustainability Issues 4(3): 271-281. http://dx.doi.org/10.9770/jesi.2017.4.3S(3)

Daher, E.; Kubicki, S.; Guerriero, A. (2017). Data-driven development in the smart city: Generative design for refugee camps in Luxembourg, Entrepreneurship and Sustainability Issues 4(3): 364-379. http://dx.doi.org/10.9770/jesi.2017.4.3S(11)

Dincer, I., \& Acar, C. (2015). A review on clean energy solutions for better sustainability. International Journal of Energy Research, 39(5), $585-606$

European Commission (2016). Energy Datasheets: EU-28 countries. Available at: https://ec.europa.eu/energy/en/data-analysis/country

Eurostat (2016). Electricity Price Statistics. Available at: http://ec.europa.eu/eurostat/statistics-explained/index.php/Electricity_price_ statistics

Ferreira, H. L., Garde, R., Fulli, G., Kling, W., \& Lopes, J. P. (2013). Characterisation of electrical energy storage technologies. Energy, 53, 288-298

García-Fuentes, M. A.; de Torre, C. (2017). Towards smarter and more sustainable regenerative cities: the REMOURBAN model, Entrepreneurship and Sustainability Issues 4(3): 328-338. http://dx.doi.org/10.9770/jesi.2017.4.3S(8)

Gârleanu, N., Panageas, S., \& Yu, J. (2015). Financial Entanglement: A Theory of Incomplete Integration, Leverage, Crashes, and Contagion. The American Economic Review, 105(7), 1979-2010

Gillingham, K., Rapson, D., \& Wagner, G. (2016). The rebound effect and energy efficiency policy. Review of Environmental Economics and Policy, 10(1), 68-88

Jaeger, M. D., \& Michaelowa, K. (2015). Global climate policy and local energy politics: Is India hiding behind the poor? Climate Policy, $1-12$

Jahn, D., Korolczuk, S. (2012). German exceptionalism: the end of nuclear energy in Germany! Environmental Politics, 21(1), $159-164$.

Joumard, I. (2001). Tax systems in European Union countries. OECD Economic Papers

Karanfil, F., \& Li, Y. (2015). Electricity consumption and economic growth: exploring panel-specific differences. Energy Policy, 82, $264-277$

Kasperowicz, R. (2014). Economic growth and energy consumption in 12 European countries: a panel data approach. Journal of International Studies, 7(3), 112-122

Kasperowicz, R. (2015). Economic growth and CO2 emissions: The ECM analysis. Journal of International Studies, 3(3), 90-97

Khalfallah, H. (2015). Connecting Mediterranean countries through electricity corridors: New Institutional Economic and regulatory analysis. Utilities Policy,32, 45-54

Koohi-Kamali, S., Tyagi, V. V., Rahim, N. A., Panwar, N. L., \& Mokhlis, H. (2013). Emergence of energy storage technologies as the solution for reliable operation of smart power systems: A review. Renewable and Sustainable Energy Reviews, 25, 135-165

Le Coq, C., \& Paltseva, E. (2009). Measuring the security of external energy supply in the European Union. Energy Policy, 37(11), 4474-4481.

Lynch, P.; Power, J.; Hickey, R.; Messrevey, T. (2017). Business model strategies: Flexibility trade in emerging low voltage distribution networks, Entrepreneurship and Sustainability Issues 4(3): 380-391. http://dx.doi.org/10.9770/jesi.2017.4.3S(12)

Maltby, T. (2013). European Union energy policy integration: A case of European Commission policy entrepreneurship and increasing supranationalism. Energy policy, 55, 435-444.

Marques, C. P., Almeida, D. (2013). A Path Model of Attitudinal Antecedents of Green Purchase Behaviour, Economics \& Sociology, 
Martínez, C. I. P., \& Piña, W. H. A. (2016). Regional analysis across Colombian departments: A non-parametric study of energy use. Journal of Cleaner Production, 115, 130-138

Menegaki, A. N. (2011). Growth and renewable energy in Europe: A random effect model with evidence for neutrality hypothesis. Energy Economics, 33(2), 257-263.

Moss, T. W., Neubaum, D. O., \& Meyskens, M. (2015). The effect of virtuous and entrepreneurial orientations on microfinance lending and repayment: A signaling theory perspective. Entrepreneurship Theory and Practice, 39(1), 27-52

O’Keeffe, J. M., Gilmour, D., \& Simpson, E. (2016). A network approach to overcoming barriers to market engagement for SMEs in energy efficiency initiatives such as the Green Deal. Energy Policy, 97, 582-590

Oates, M.; Melia, A.; Ferrando, V. (2017). Energy balancing accross cities: Virtual Power Plant prototype and iURBAN case studies, Entrepreneurship and Sustainability Issues 4(3): 351-363. http://dx.doi.org/10.9770/jesi.2017.4.3S(10)

Passerini, F.; Sterling, R.; Keane, M.; Klobut, K.; Costa, A. (2017). Energy efficiency facets: innovative district cooling systems, Entrepreneurship and Sustainability Issues 4(3): 310-318. http://dx.doi.org/10.9770/jesi.2017.4.3S(6)

Perfido, D.; Raciti, M.; Zanotti, C.; Chambers, N.; Hannon, L.; Keane, M.; Clifford, E.; Costa, A. (2017). Towards sustainable water networks: automated fault detection and diagnosis, Entrepreneurship and Sustainability Issues 4(3): 339-350. http://dx.doi.org/10.9770/ jesi.2017.4.3S(9)

Puffer, S. M., McCarthy, D. J., \& Jaeger, A. M. (2016). Institution building and institutional voids: Can Poland's experience inform Russia and Brazil?.International Journal of Emerging Markets, 11(1), 18-41

Rezk, M. A.; Ibrahim, H. H.; Radwan, A.; Sakr, M. M.; Tvaronavičienè, M.; Piccinetti, L. (2016). Innovation magnitude of manufacturing industry in Egypt with particular focus on SMEs, Entrepreneurship and Sustainability Issues 3(4): 306-318. http://dx.doi.org/10.9770/ jesi.2016.3.4(1)

Rezk, M. A.; Ibrahim, H. H.; Radwan, A.; Sakr, M. M.; Tvaronavičienė, M.; Piccinetti, L. (2016). Innovation magnitude of manufacturing industry in Egypt with particular focus on SMEs, Entrepreneurship and Sustainability Issues 3(4): 306-318. http://dx.doi.org/10.9770/ jesi.2016.3.4(1)

Richter, P. M., \& Holz, F. (2015). All quiet on the eastern front? Disruption scenarios of Russian natural gas supply to Europe. Energy Policy, 80, 177-189

Ríos-Mercado, R. Z., \& Borraz-Sánchez, C. (2015). Optimization problems in natural gas transportation systems: A state-of-the-art review. Applied Energy, 147, 536-555

Rutland, P. (2008). Russia as an energy superpower. New Political Economy, 13(2), 203-210.

Scarlat, N., Dallemand, J. F., Monforti-Ferrario, F., Banja, M., \& Motola, V. (2015). Renewable energy policy framework and bioenergy contribution in the European Union-An overview from National Renewable Energy Action Plans and Progress Reports. Renewable and Sustainable Energy Reviews, 51, 969-985

Šimelytė, A.; Ševčenko, G.; El Amrani El Idrissi, N.; Monni, S. (2016). Promotion of renewable energy in Morocco, Entrepreneurship and Sustainability Issues 3(4): 319-328. http://dx.doi.org/10.9770/jesi.2016.3.4(2)

Šimelytė, A.; Ševčenko, G.; El Amrani El Idrissi, N.; Monni, S. (2016). Promotion of renewable energy in Morocco, Entrepreneurship and Sustainability Issues 3(4): 319-328. http://dx.doi.org/10.9770/jesi.2016.3.4(2)

Sovacool, B. K., \& Dworkin, M. H. (2015). Energy justice: Conceptual insights and practical applications. Applied Energy, 142, 435-444

Stern, P. C. (2014). Individual and household interactions with energy systems: toward integrated understanding. Energy Research \& Social Science, 1, 41-48

Štreimikienè, D., Kasperowicz, R. (2016). Review of economic growth and energy consumption: A panel cointegration analysis for EU countries. Renewable and Sustainable Energy Reviews, 59, 1545-1549

Strielkowski, W. (2016). Entrepreneurship, sustainability, and solar distributed generation, Entrepreneurship and Sustainability Issues 4(1): 9-16. http://dx.doi.org/10.9770/jesi.2016.4.1(1)

Strielkowski, W. (2016). Entrepreneurship, sustainability, and solar distributed generation, Entrepreneurship and Sustainability 
Issues 4(1): 9-16. http://dx.doi.org/10.9770/jesi.2016.4.1(1)

Szulecki, K., Fischer, S., Gullberg, A. T., \& Sartor, O. (2016). Shaping the 'Energy Union': between national positions and governance innovation in EU energy and climate policy. Climate Policy, 1-20

The Economist (2013). How to lose half a trillion euros (12.06.2013). Available at: http://www.economist.com/news/briefing/21587782europes-electricity-providers-face-existential-threat-how-lose-half-trillion-euros

Timmer, M. P., Los, B., Stehrer, R., \& De Vries, G. J. (2013). Fragmentation, incomes and jobs: an analysis of European competitiveness. Economic policy, 28(76), 613-661

Traversari, R.; Den Hoed, M.; Di Giulio, R.; Bomhof, F. (2017). Towards sustainability through energy efficient buildings design: semantic labels, Entrepreneurship and Sustainability Issues 4(3): 243-256. http://dx.doi.org/10.9770/jesi.2017.4.3S(1)

Tvaronavičienė, M. (2016). Entrepreneurship and energy consumption patterns: case of households in selected countries, Entrepreneurship and Sustainability Issues 4(1): 74-82. http://dx.doi.org/10.9770/jesi.2016.4.1(7)

Tvaronavičienė, M. (2016). Entrepreneurship and energy consumption patterns: case of hoseholds in selected countries, Entrepreneurship and Sustainability Issues 4(1): 74-82. http://dx.doi.org/10.9770/jesi.2016.4.1(7)

Umbach, F. (2010). Global energy security and the implications for the EU. Energy Policy, 38(3), 1229-1240.

Urbaniec, M. (2015), Towards Sustainable Development through Ecoinnovations: Drivers and Barriers in Poland, Economics and Sociology, 8(4), pp. 179-190. DOI: 10.14254/2071-789X.2015/8-4/13

Vasseur, V., \& Kemp, R. (2015). The adoption of PV in the Netherlands: A statistical analysis of adoption factors. Renewable and Sustainable Energy Reviews, 41, 483-494

Whist, B. S. (2007). Nord Stream: Not Just a Pipeline. FNI Report 15/2008. Available at: http://kms1.isn.ethz.ch/serviceengine/Files/ ISN/94432/ipublicationdocument_singledocument/382de953-1a0c-4c7c-8371-7e4a39823070/en/2008_Nord+Stream.pdf

\section{YURIY BILAN}

orcid id: 0000-0003-0268-009X

\section{WADIM STRIELKOWSKI}

orcid id: 0000-0001-6113-3841

\section{GRZEGORZ MENTEL}

orcid id 0000-0002-6371-1219 